\title{
Postnatal development of the European bison spermatogenesis
}

\author{
Elżbieta CZYKIER, Bogusław SAWICKI and Małgorzata KRASIŃSKA
}

Czykier E., Sawicki B. and Krasińska M. 1999. Postnatal development of the European bison spermatogenesis. Acta Theriologica 44: 77-90.

The testes and epididymes of the European bison Bison bonasus (Linnaeus, 1758) were collected from culled animals living in free-ranging populations in Białowieża Forest, Borecka Forest and Bieszczady Mountains, and in captivity (103 males, 4 months to 17 years old). We found that all bulls were sexually mature at the age of 4 years, and some even at the age of 3 years. Animals which started mature spermatozoa production were treated as sexually mature. We observed the inhibition of spermatogenesis efficiency and involutionary changes in epididymal epithelium after 12 years of age. Therefore, in the postnatal development of spermatogenesis three phases were distinguished: I - development of spermatogenesis (4th month -4 th year of age), II - mature spermatogenesis (4th - 12th year), III - inhibition of spermatogenesis efficiency (over 12th year of age).

Department of Histology and Embryology, Medical University, Kiliński Street 1, PL-15-230 Białystok, Poland (EC, BS); Mammal Research Institute, Polish Academy of Sciences, 17-230 Białowieża, Poland (MK)

Key words: Bison bonasus, histological structure, testis, epididymis, spermatogenesis development, senile gonadoinvolution

\section{Introduction}

The histological structure of the bison testes has been investigated previously only in adult individuals on the bases of limited material (Kulagin 1932, Korobko and Kurnosov 1979, Bomba 1995), containing too few comparative data. No information could be found in the available literature on the histology of the testes of the American bison, a representative of the same genus Bison.

A few reports which have been published on the European bison male sexual organs present anatomical descriptions only (Świeżyński 1968). Histological examinations of the testes in the hybrids (European bison and American bison on domestic cattle) have revealed a number of abnormalities in the development of spermatogenesis which frequently cause total infertility in males (Basrur 1969, Fedyk and Krasińska 1971, 1980, Korwin-Kossakowski and Sumiński 1984, Bomba 1995). Thus, their findings cannot be taken into consideration while evaluating normal histological structure of the European bison testes.

Until now, the age of sexual maturation in European bison males has been defined indirectly basing on the succesful mating with cows in captivity (Zablocki 
1949, Jaczewski 1958, Krasiński and Raczyński 1967). In our study, sexual maturation is associated with the onset of mature spermatozoa production.

Regular culling of animals from a free-ranging population carried out in the Białowieża Forest from half of the 1970s and periodically in captivity gave us a chance to examine histological structure of the testes and epididymes in animals from several classes of age. A particular aim of these studies was to thoroughly investigate the development of spermatogenesis in young individuals and to establish the very onset of spermatozoa production and ageing-related time of inhibition of spermatogenesis efficiency. However, lack of material did not allow us to investigate the season-related effect.

\section{Material and methods}

The material used for analysis was collected from the bison living in free-ranging populations mostly in Białowieża Forest, and also in Borecka Forest and Bieszczady Mountains (92 individuals aged 4 months - 17 years) (Table 1 ). It was collected mainly in winter (55.4\%), but also in other seasons,

The other group of material was obtained from the bison kept in reserves such as Białowieża, Pszczyna, Gołuchów, in various months of the year (11 individuals aged 2-12 years) (Table 1). It was settled that if the results of the study on spermatogenesis development and its activity in sexually mature individuals did not differ between both groups, the whole material would be studied jointly.

The animals were culled in the years 1969-1993 for several reasons, including a reduction in number, injuries, poaching or a male disease defined as necrotic balanoposthitis (Krasiński et al. 1994). The relatively abundant material $(n=46)$ was obtained from the males with pathological changes localized in the prepuce and penis region, defined as necrotic balanoposthitis (Piusiński et al. 1997). No changes were observed in the region of the scrotum or testes in these males. The diseased males usually were in good condition (Krasiński 1994), and adult individuals displayed normal sexual activity. Histology of the testes did not differ from those of the healthy males in the same age, the whole material would be studied jointly. Culled animals were provided always in the same way. The material for histological investigations was collected by workers of Białowieża National Park (BNP) and Mammal Research Institute, Polish Academy of Sciences in Białowieża, and prepared. Sections from the upper pole of the left testis and, separately, fragments of the epididymal corpus were obtained for examination. The material was fixed in Bouins fluid; $6 \mathrm{~m}$ paraffin sections were stained with hematoxylin and eosin $(\mathrm{H}+\mathrm{E})$, and with Azan method. Microscopic preparations of the testes and the epididymes were subjected to histological examination using a light microscope (maximum

Table 1. Age and number of the European bison examined.

\begin{tabular}{|c|c|c|c|c|c|c|c|}
\hline \multirow{3}{*}{ Origin from: } & \multicolumn{6}{|c|}{ Age class } & \multirow{3}{*}{ Tota } \\
\hline & \multirow{2}{*}{$\begin{array}{c}\text { Calves } \\
\leq 1 \text { year } \\
\text { old }\end{array}$} & \multicolumn{2}{|c|}{ Juveniles } & \multicolumn{3}{|c|}{ Adults } & \\
\hline & & $\begin{array}{l}2 \text { years } \\
\text { old }\end{array}$ & $\begin{array}{l}3 \text { years } \\
\text { old }\end{array}$ & $\begin{array}{c}4-5 \text { years } \\
\text { old }\end{array}$ & $\begin{array}{c}6-12 \text { years } \\
\text { old }\end{array}$ & $\begin{array}{c}>12 \text { years } \\
\text { old }\end{array}$ & \\
\hline Free-ranging & 18 & 17 & 10 & 15 & 25 & 7 & 92 \\
\hline Enclosed reserves & 0 & 2 & 3 & 2 & 3 & 1 & 11 \\
\hline Total & 18 & 19 & 13 & 17 & 28 & 8 & 103 \\
\hline
\end{tabular}


magnification-1000x). The state of spermatogenesis was estimated basing on the presence of various developmental phases of germinal cells in seminiferous tubules (from spermatogonium through spermatocytes and spermatids to spermatozoa), diameter size of these tubules, differentiation of the epididymal head and corpus epithelium and the presence of spermatozoa in the testes and epididymes. The diameter of seminiferous ductules, efferent ductules and epididymal duct was measured in histological preparations, on 20 round cross - sections per each testis (Table 2). The animals were divided into 6 age groups (Table 1), considering time of puberty, sexual maturity, active reproductive state and ageing (Krasiński 1978, Caboń-Raczyńska et al. 1983). The age of bison was established by Z. A. Krasiński (BNP) according to a sequence of tooth erruption and degree of tooth wear (Węgrzyn and Serwatka 1984).

\section{Results}

\section{Calves ( $\leq 1$ year old )}

The histological picture of the testes in the group of calves ( 4 months to 1 year) showed change ability. In the youngest calves (4 months old), the testes were characterized by narrow seminiferous tubules with the transverse section diameter $46.22 \pm 2.6 \mu \mathrm{m}$. The seminiferous tubules had no lumen and were seen in a certain distance from one another. The space between them was filled with very loose connective tissue (Fig. 1). Only in some areas single Leydig cells with eosinophilic cytoplasm could be observed between the tubules. The basement membrane of the seminiferous tubules was more than $2 \mu \mathrm{m}$ thick, surrounded by a single discontinued layer of flattened myofibroblasts containing scanty cytoplasm (Fig. 1). Only in the vicinity of blood vessels, these cells showed more compact arrangement. In that period, germinal epithelium was formed by densely lying elongated supporting cells (Sertoli cells). All the seminiferous tubules displayed single large and round spermatogonia (in the number of 1-3 on the cross-section), most frequently situated above the nuclei of the Sertoli cells. However, in the one-year old calves the seminiferous tubules of the testes showed increased translucence of the central part (Fig. 2). Germinal cells were still seen in a small number (Fig. 2). Loose connective tissue between the tubules was decreased in the testis lobule and its texture became more compact (Fig. 2). The cross-section diameter of the seminiferous tubules was unchanged, but they occurred in larger numbers and were more twisted. The efferent ductules of the 4-month-old animals had a narrow lumen; the diameter on the transverse cross-section was $98.16 \pm 4.1 \mu \mathrm{m}$. The ductules showed homogenous cylindrical unplicated epithelium and were enclosed by a continuous layer of myofibroblasts. The epididymal duct had a narrow lumen, though a little wider than that of the ductules, its cross-section reaching 279.22 $\pm 4.3 \mu \mathrm{m}$ in diameter. The duct was lined with low pseudostratified columnar epithelium with very short stereocilia (Fig. 3). The epididymal duct was surrounded by a thicker layer of myofibroblasts compared with the efferent ductules. The lumen of the ductules and epididymal duct was devoid of spermatozoa. The microscopic picture of the epididymes of the one-year-old animals was similar to that observed in the group of the 4-month-old ones (Table 2). 


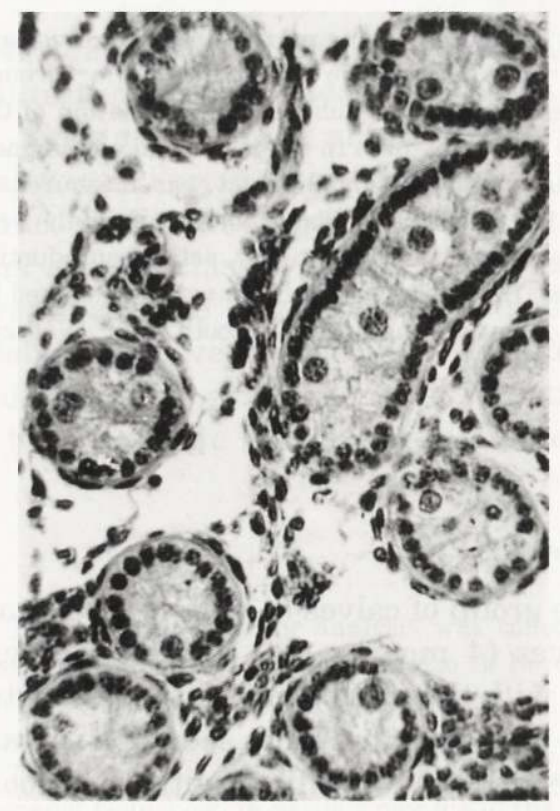

Fig. 1. Male, aged 4 months. Fragment of the testis. Seminiferous tubules are devoid of lumen, have a small transverse cross-section diameter and lie in a certain distance from one another. Germinal epithelium shows a predominance of Sertoli cells; young spermatogonia (1-3 in number) are most frequently situated above the nuclei of these cells. $\mathrm{H}+\mathrm{E}$. Magnification $\times 330$.

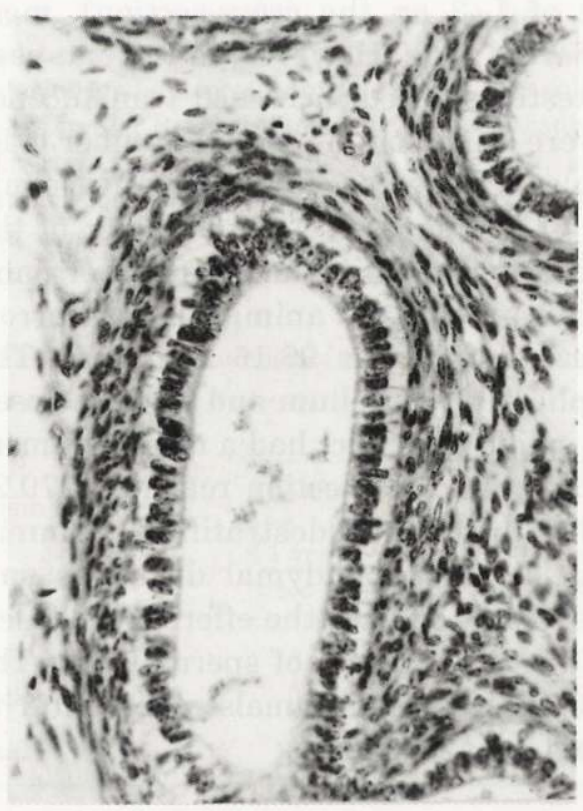

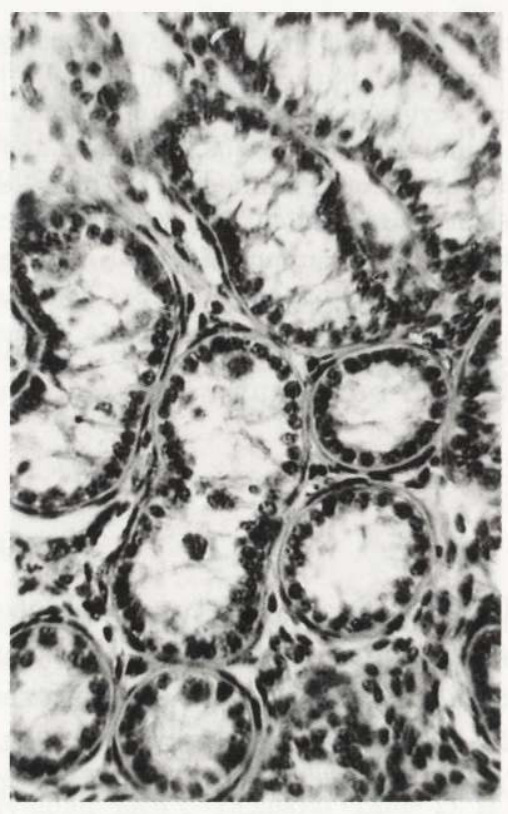

Fig. 2. Male, aged 1 year. Fragment of the testis. The central part of the seminiferous tubules shows increased translucence. Germinal cells are still rare, the testicular lobule displays a decreased amount of loose connective tissue situated between the tubules. $\mathrm{H}+\mathrm{E}$. Magnification $\times 330$.

Fig. 3. Male, aged 5 months. Fragment of the epididymis. The epididymal duct is lined with low pseudostratified columnar epithelium having very short stereocilia. $\mathrm{H}+\mathrm{E}$. Magnification $\times$ 340 . 
Table 2. Measurements of the diameter of seminiferous ductules, efferent ductules and epididymal duct in the European bison.

\begin{tabular}{|c|c|c|c|c|c|c|c|}
\hline \multirow[t]{2}{*}{ Age } & \multirow[t]{2}{*}{$n$} & \multicolumn{2}{|c|}{$\begin{array}{c}\text { Diameter of seminiferous } \\
\text { tubules }(\mu \mathrm{m})\end{array}$} & \multicolumn{2}{|c|}{$\begin{array}{c}\text { Diameter of efferent } \\
\text { ductules }(\mu \mathrm{m})\end{array}$} & \multicolumn{2}{|c|}{$\begin{array}{c}\text { Diameter of epididymal } \\
\text { duct }(\mu \mathrm{m})\end{array}$} \\
\hline & & Mean \pm SD & Range & Mean \pm SD & Range & Mean \pm SD & Range \\
\hline$\leq 1$ year old & 18 & $46.22 \pm 2.6$ & $42-51$ & $98.16 \pm 4.1$ & $90-105$ & $279.22 \pm 4.3$ & $270-290$ \\
\hline 2 years old & 19 & $68.52 \pm 2.5$ & $64-73$ & $99.36 \pm 3.5$ & $90-105$ & $278.89 \pm 3.9$ & $268-283$ \\
\hline 3 years old & 13 & $69.84 \pm 2.6$ & $65-73$ & $159.84 \pm 3.6$ & $153-166$ & $277.53 \pm 7.0$ & $265-285$ \\
\hline 4-5 years old & 17 & $122.76 \pm 5.7$ & $111-132$ & $449.94 \pm 7.2$ & $439-461$ & $581.52 \pm 5.4$ & $570-590$ \\
\hline $6-12$ years old & 28 & $121.60 \pm 4.5$ & $114-130$ & $450.50 \pm 5.3$ & $440-460$ & $579.35 \pm 6.3$ & $567-591$ \\
\hline$>12$ years old & 8 & $173.75 \pm 3.5$ & $130-220$ & $461.12 \pm 6.1$ & $455-475$ & $655.0 \pm 13.3$ & $640-680$ \\
\hline
\end{tabular}

\section{Juveniles two years old}

The testicular lobules of the two-year-old animals had seminiferous tubule diameters increased to $68.52 \pm 2.52 \mu \mathrm{m}$. A narrow and irregular tubular lumen appeared. Supporting cells were still predominant in spermatogenic epithelium.

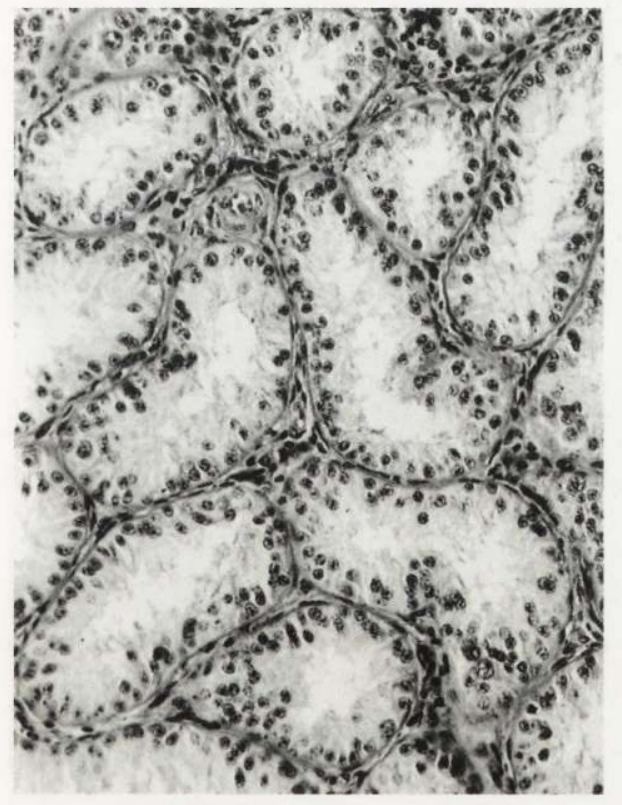

Fig. 4. Male, aged 2 years. Fragment of the testis. Seminiferous tubules show increased tortuosity, enlarged diameter and there is a considerably decreased amount of loose connective tissue between them. Sertoli cells still dominate in the tubules. $\mathrm{H}+\mathrm{E}$. Magnification $\times 240$.

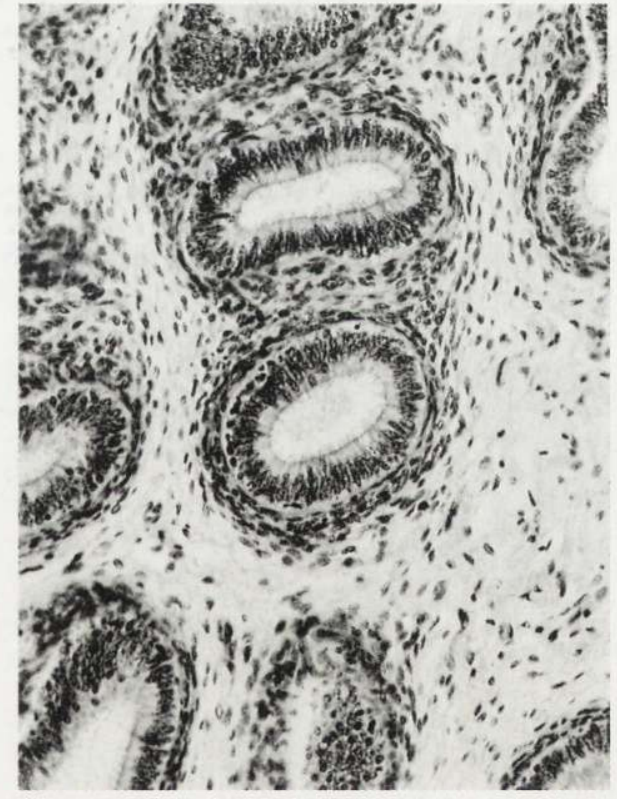

Fig. 5. Male, aged 2 years. Fragment of the epididymis. The epididymal duct shows pseudostratified columnar epithelium with slightly longer stereocilia. $\mathrm{H}+\mathrm{E}$. Magnification $\times 120$. 
The Sertoli cell processes frequently combined with the cells of the opposite side and then the lumen almost disappeared. Few spermatogonia were localized close to the basement membrane of the tubules (Fig. 4). Clusters of Leydig cells were seen between some of the seminiferous tubules.

The microscopic picture of the epididymal head did not differ significantly from the one observed in young animals (Table 2). However, the epididymal duct showed a bit longer stereocilia on the surface of pseudostratified columnar epithelium (Fig. 5 ). The lumen of the epididymal duct was still narrow and devoid of spermatozoa (Fig. 5).

\section{Juveniles three years old}

The testes of the 3-year-old animals contained seminiferous tubules lying densely side by side in the lobules and were considerably more twisted. Their diameter reached $69.84 \pm 2.64 \mu \mathrm{m}$. They had a wider lumen which usually showed cellular debris. In 3 ( 2 bison from reserves and 1 free-ranging) out of 13 animals some tubules contained spermatozoa (Fig. 6). A small amount of loose connective tissue was observed between the tubules, though with texture more compact than in the younger animals. Myoidal cells arranged in 2 tight layers were closely attached to the basement membrane of the seminiferous tubules (Fig. 6). All developmental phases of germinal cells, more numerous than Sertoli cells, could

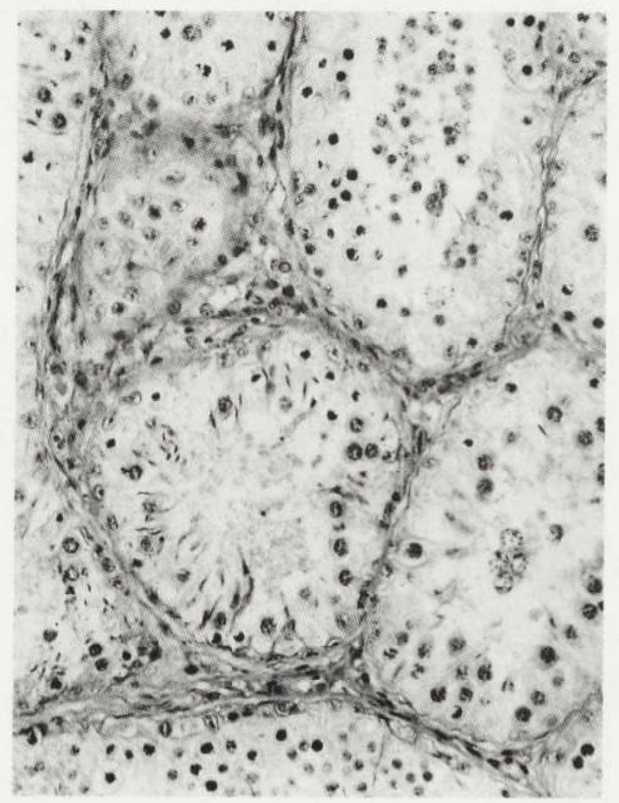

Fig. 6. Male, aged 3 years. Fragment of the testis. The seminiferous tubules of some of the animals contained late spermatids. $\mathrm{H}+\mathrm{E}$. Magnification $\times 280$.

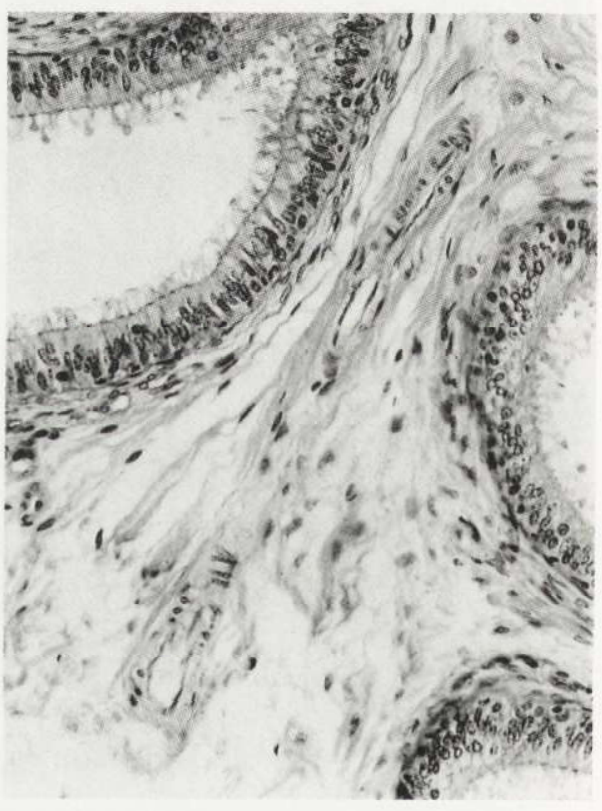

Fig. 7. Male, aged 3 years. Fragment of the epididymis. The epididymal duct has larger diameter and shows spermatozoa in those few animals which have started the production of spermatozoa. $\mathrm{H}+\mathrm{E}$. Magnification $\times 240$. 
be observed in germinal epithelium (Fig. 6). Nests and bands of Leydig cells were more common between the seminiferous tubules.

Efferent ductules of the testis were enlarged and were $159.84 \pm 3.6 \mu \mathrm{m}$ in diameter. In most animals, the ductules devoid of spermatozoa showed one-layer columnar unplicated epithelium. In single juveniles, epithelial plications and a small number of spermatozoa were seen in the ductular lumen. The epididymal duct was wider, with the transverse cross-section reaching $277.53 \pm 7.0 \mu \mathrm{m}$; in most animals, it contained no spermatozoa and was lined with pseudostratified columnar epithelium showing low stereocilia. Individuals with spermatozoa in the seminiferous tubules of the testis had higher columnar epithelium and spermatozoa in the lumen of the epididymal duct (Fig. 7).

\section{Four and five years old bulls}

Their testis seminiferous tubules were $122.76 \pm 5.7 \mu \mathrm{m}$ in diameter. The tubular basement membrane, $3 \mu \mathrm{m}$ thick, was enclosed by a continuous layer of myoidal cells and externally localized cell-rich loose connective tissue proper with a dominance of fibroblasts. Spermatogenic series cells markedly prevailed in germinal epithelium. Some tubules showed spermatozoa (Fig. 8), others had only spermatids

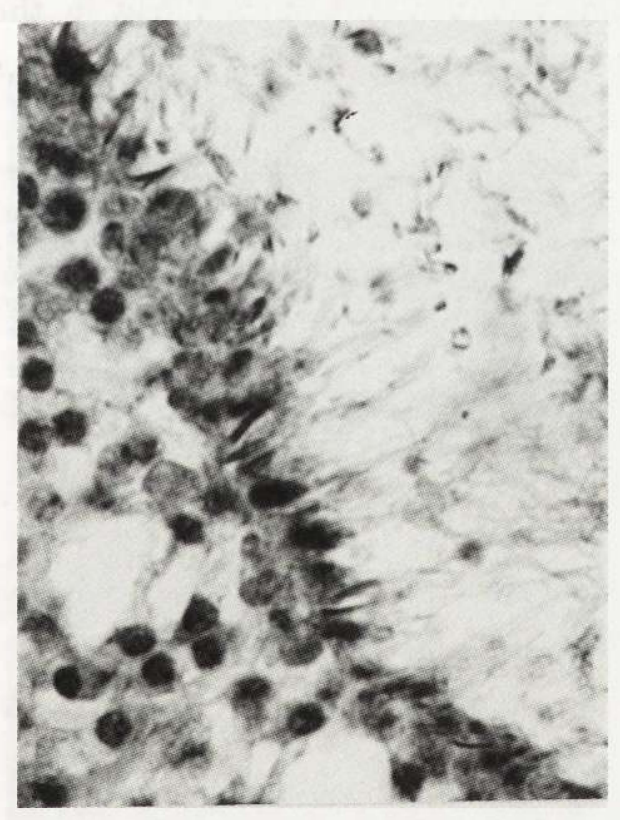

Fig. 8. Male, aged 4 years. Fragment of the seminiferous tubules. Germinal epithelium shows a predominance of spermatogenesis cells. $\mathrm{H}+\mathrm{E}$. Magnification $\times 360$.

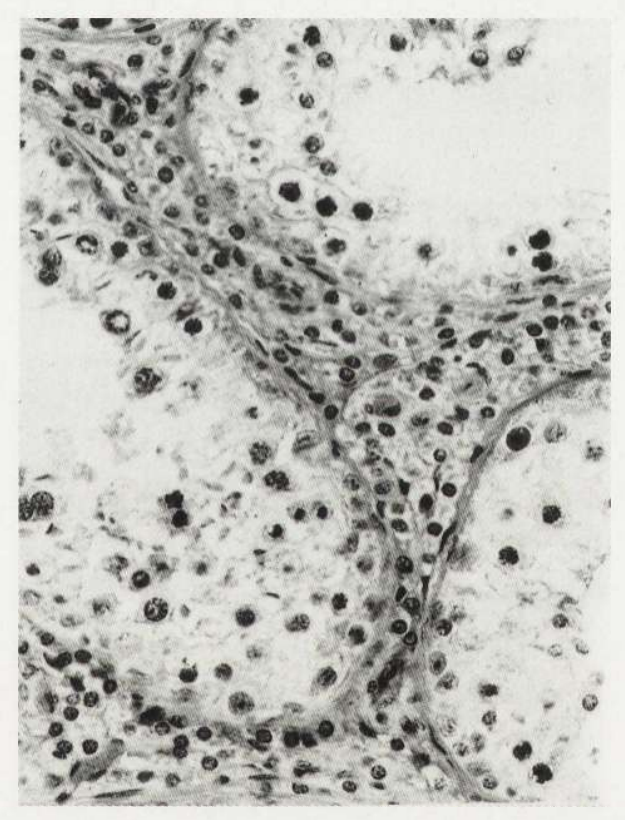

Fig. 9. Male, aged 4 years. Fragment of the testis. Nests of Leydig cells are visible among the seminiferous tubules. $\mathrm{H}+\mathrm{E}$. Magnification $\times$ 310 . 
at different development phases. Numerous nests of Leydig cells were seen between the tubules (Fig. 9).

In the 4-5 age group both the efferent ductules of the testis and the duct of the epididymis became enlarged, reaching $449.94 \pm 7.2 \mu \mathrm{m}$ and $581.52 \pm 5.4 \mu \mathrm{m}$ in diameter. The efferent ductules showed monolayer plicated epithelium with cylindrical and cuboid cells, presenting a characteristic lumen with numerous sinuses. High pseudostratified columnar epithelium with long stereocilia was observed in the epididymal duct (Fig. 10). The lumen of the efferent ductules and epididymal duct showed a large number of spermatozoa (Fig. 10). The own membrane of the epididymal duct contained more smooth muscle cells than efferent ductules of the testis.

\section{Six to twelve years old bulls}

The microscopic picture of the testes and epididymes was similar to that of the 4-5 age group. However, the material obtained from the males culled in the period between September and November which falls on the rutting time (August-October) (Jaczewski 1958, Krasiński and Raczyński 1967, Caboń-Raczyńska et al. 1983) proved intensified spermatogenesis. This referred both to the animals living in free-ranging populations and in reserves, and was manifested in more numerous spermatozoa in the seminiferous tubules, and particularly in the

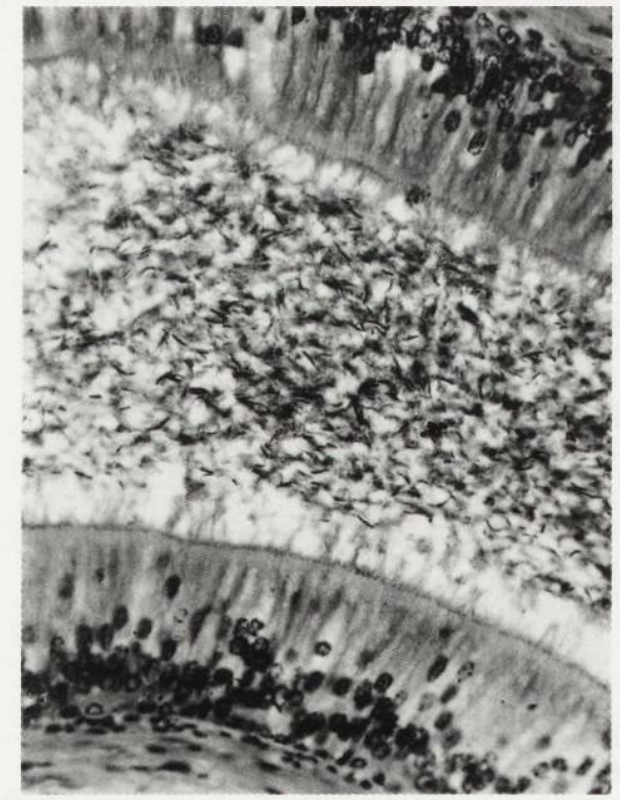

Fig. 10. Male, aged 4 years. Fragment of the epididymal duct. The epididymal lumen shows very numerous spermatozoa. $\mathrm{H}+\mathrm{E}$. Magnification $\times 340$.

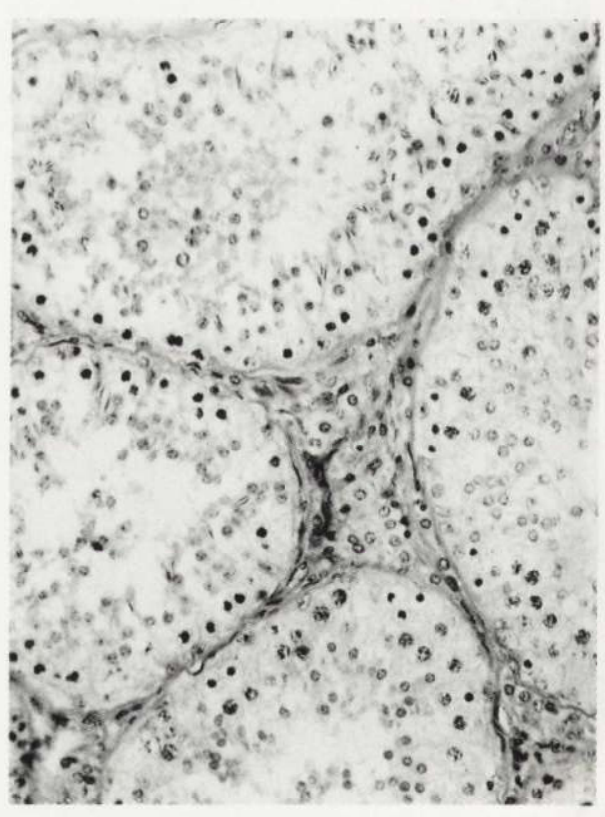

Fig. 11. Male, aged 15 years. Fragment of the testis. Seminiferous tubules are distended disproportionately to very few spermatozoa in the tubular lumen. $\mathrm{H}+\mathrm{E}$. Magnification $\times 240$. 
enlargement of the number of germinal cells at various developmental phases. However, degenerative germinal cells, numerous in the lumen of the seminiferous tubules beyond the rutting period, disappeared. The epididymal duct in the rutting time was filled with numerous spermatozoa. Some diseased individuals showed active spermatogenesis in winter months (January, February) comparable to the rutting period.

\section{Over 12 years old bulls}

In this age group seminiferous tubules were $173.75 \pm 3.5 \mu \mathrm{m}$ in diameter due to a markedly widened lumen. Some tubules had neither spermatozoa nor late spermatids (Fig. 11). Connective tissue contained colloidal masses between the tubules, the number of Leydig cells was reduced (Fig. 11).

The efferent ductules of the testis were $461.12 \pm 6.1 \mu \mathrm{m}$ in diameter and were lined with monolayer plicated epithelium, much higher than in the 6-12 age group. Colloidal masses were more common than spermatozoa (Fig. 12). The tubular wall showed more layers of smooth muscle cells. The diameter of the epididymal duct was enlarged to $655.0 \pm 13.3 \mu \mathrm{m}$, the duct was distended, considerably twisted and covered with high pseudostratified columnar epithelium containing large groups of vacuolized light cells. The ductal lumen showed colloidal masses, more

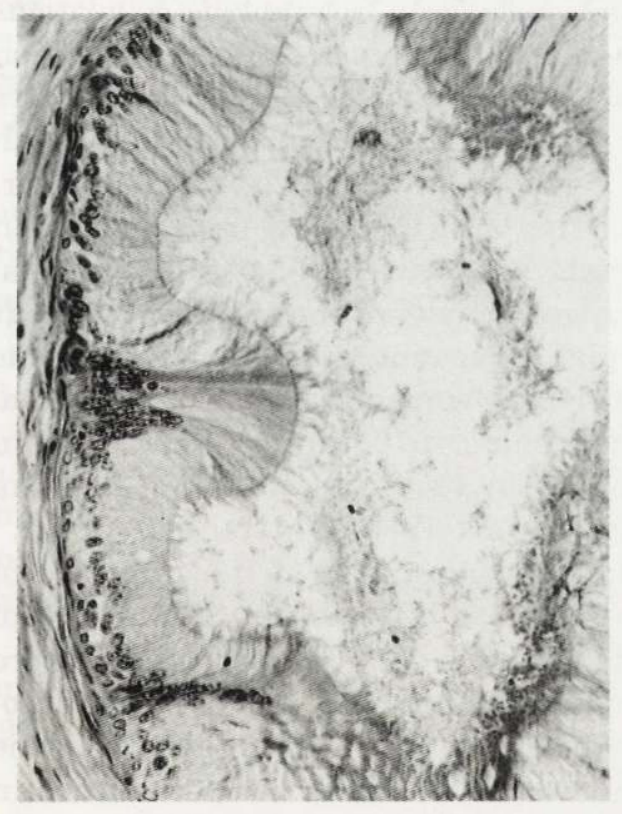

Fig. 12. Male, aged 15 years. The efferent ductules of the testis. The epithelium of the efferent ducts is high, the ductular lumen shows a predominance of colloidal masses over spermatozoa. $\mathrm{H}+\mathrm{E}$. Magnification $\times 240$.

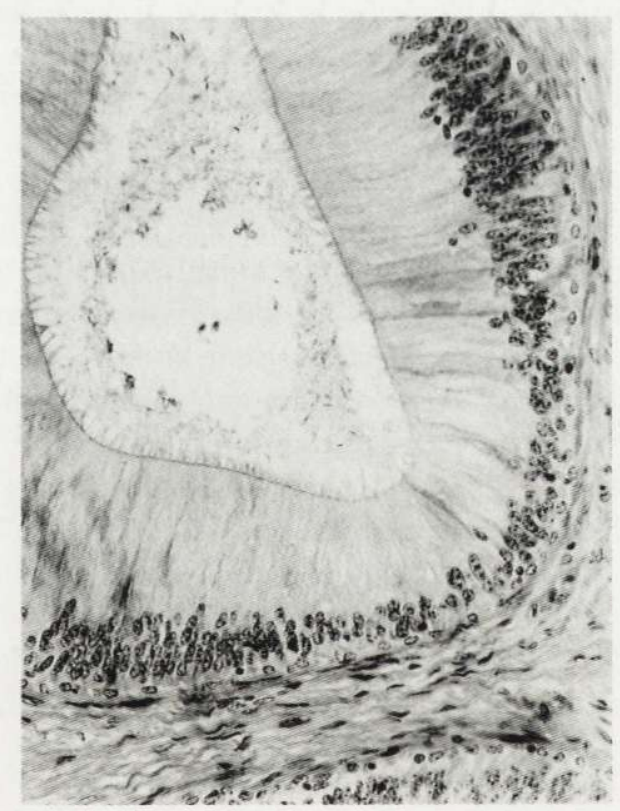

Fig. 13. Male, aged 15 years. Fragment of the epididymal duct. The epididymal duct is distended and highly tortuous. Its lumen shows a predominance of colloidal masses. Spermatozoa are sporadic. $\mathrm{H}+\mathrm{E}$. Magnification $\times 240$. 
rarely spermatozoa (Fig. 13). Spermatozoa were less numerous than in the 6-12 age group. More smooth muscle cells than in the younger age group were found in the ductal membrane. The epididymal duct and efferent ductules of the testes were distended disproportionately to a small number of spermatozoa present in the epididymes (Figs 12 and 13).

Basing on histological analysis of the testes and epididymes, three phases of spermatogenesis can be distinguished in the postnatal development: I - development of spermatogenesis (resulting in full spermatogenesis), II - mature spermatogenesis, III - inhibition of spermatogenesis efficiency. Phase I referred to the postnatal development and included animals aged 4 months -4 years. Phase II referred to the 4-12 age group, while phase III to the over 12 years old bulls.

\section{Discussion}

The analysed material came from the European bison living in freedom and in reserves. The study on the postnatal development of spermatogenesis and on the activity of spermatogenesis in adult bulls showed no significant differences between both groups. Thus, the material was treated jointly.

The differences in European bison reproduction between free-ranging populations and those living in reserves referred to higher fertility of females and prolongation of the rutting season in reserves (Krasiński and Raczyński 1967). The authors associated the differences in reproduction between the two bison groups with supplementary food provided in reserves throughout the year. We think, however, that the differences in the nourishment of the bison living in freedom and in reserves are not so significant as to affect the activity of spermatogenesis. Mammals do not exhibit identical spermatogenic activity of the testes throughout the year. In domesticated animals (cattle, pig) a constant state of spermatogenic activity is observed. Among wild mammals there are numerous examples of seasonal cycles in testicular activity (Chapman and Chapman 1970, Lincoln 1971, Chaplin and White 1972, Hocherau de Rivers and Lincoln 1978, Lincoln 1981, Raitsina 1985, Loudon and Curlewis 1988, Gosch and Fischer 1989, Webster et al.1992).

The analysed material did not allow full understanding of the influence of season on the spermatogenic activity of the European bison testes. Since $87.4 \%$ of the material was obtained in the period that followed the rut, spermatozoa were still found in the testes and epididymes. However in the post-rut period spermatozoa were still found in the testes and epididymis, but less numerous than in the rut season. In the age group of 4-12 years, the males had more spermatozoa in the epididymal duct from September to November, which indicated the enhanced spermatogenic activity in that period. In the European bison living in captivity successful matings were observed beyond the rutting period (winter-spring), which may suggest spermatogenic activity of the bison testes throughout the year. However, marked reproduction seasonality (August-October) observed in free 
breeding may result from hormone secretion and may obviously be a response to reproductive readiness of females.

Phase I (development of spermatogenesis)

Phase I referred to the postnatal development and included animals aged 4 months -4 years. In this age group the testes were found to grow from immature gonads to fully developed typical germinal epithelium. Initially, the germinal epithelium showed dominance of the Sertoli cells, while at the end of the 3rd year germinal cells began to prevail. A similar histological pattern of the testes was described by other investigators in sexually immature wild ungulates such as fallow deer (Chapman and Chapman 1970, Chaplin and White 1972), and red deer (Webster et al. 1992). In our observations immaturity of spermatogenesis in testicular seminiferous tubules correlated with underdevelopment of the epididymal head and body epithelium. The growth of bison calves was accompanied by testicular and epididymal maturation. The one-year-old bison males showed increased translucence in the central part of seminiferous tubules, while the two-year-old animals had a lumen in their seminiferous tubules, although germinal epithelium was still immature, lacking spermatozoa. Also Wróblewski (1927) found no spermatozoa in seminiferous tubules in the young two and two-and-a half years old bison males. In the three-year-old males, however, we observed pronounced intensification of changes in the structure of the testes associated with their maturation.

Our investigations have revealed that certain percentage of males (3 out of 13) can reach sexual maturity at 3 years of age, but as a rule all 4 years old males are sexually mature. This is consistent with the conclusions of other authors who basing on successful matings in captivity have established that most bulls mate with females at the age of over 3 years (Krasiński and Raczyński 1967). According to Zablocki (1949) and Jaczewski (1958) male bison in captivity could achieve sexual maturity at the age of 15-16 months at the earliest. The American bison males reach sexual maturity earlier than the European bison. The analysis of smear from the epididymes of the American bison revealed the presence of spermatozoa in 2 out of 6 yearlings, in 5 out of 6 two-year-old, in 4 out of 5 three-year-old and in all 4-year-old individuals (Shult 1972).

The young, sexually mature European bison males do not participate in the rut in free-ranging populations because of certain interpopulation factors (Krasiński 1967, Krasiński and Raczyński 1967).

\section{Phase II (full sexual maturity)}

Phase II (4-12 years of age) exhibited typical germinal epithelium in the seminiferous tubules, similar to that already described in other mammals (Basrur 1969), numerous Leydig cells arranged in nests in the interstitial connective tissue 
of the testes, and differentiated epithelium of the epididymal head and corpus with a large number of spermatozoa in the tubular lumen. The histological pattern of spermatogenesis observed in the 4-12 years old males of the European bison is consistent with previous data of Kulagin 1928, Korobko and Kurnosov 1979, Bomba 1995. The same was truth for sexually active wild ungulates such as axis deer, red deer, fallow deer (Chapman and Chapman 1970, Lincoln 1971, Chaplin and White 1972, Loudon and Curlewis 1988, Webster et al. 1992) and domestic cattle (Bomba 1995). We found no changes in gonad histology in the 6-year-old animals, compared to a little younger group.

Our results confirming full sexual maturity of European bison males at 4 years of age are in agreement with the observations of sexual behaviour of males and their participation in reproduction. In the rutting period, the 6-12 years old bulls, fully physically developed, dominate in reproduction, the young 4-5 years old sexually mature males show interest in the rutting cows but are not admitted to them by the dominant bulls (Caboń-Raczyńska et al. 1987, Krasiński and Krasińska 1992, Krasińska and Krasiński 1995). A similar situation is observed in the American bison, where young bulls do not form tending bonds with the rutting cows, but accompany them as the so called "satellite" bulls (Haugen 1974).

Phase III (spermatogenesis efficiency inhibition).

In this period we observed degenerative alterations in histological structure of the testes (appearance of colloidal masses in the connective tissue, marked distension of the seminiferous tubules with a reduced number of spermatozoa and Leydig cells in the connective tissue). Degenerative lesions were also observed in the epididymes. These degenerative alterations were not observed in the group of 6-12 years old bulls in the same season. Thus they cannot be the effect of post-rut involution. Ageing-related alterations found in our study in the testes and epididymes correlated with sexual behavior of the animals. According to Kulagin (1919) bulls can achieve fertile matings up to the age of 10 .

Most recent investigations done in free-ranging populations of the European bison living in Białowieża Forest and Borecka Forest reveal that the age of 11-12 years can be the top limit of active participation of males in reproduction (Caboń-Raczyńska et al. 1987, Krasiński and Krasińska 1992, Krasińska and Krasiński 1995). Behavioral observations do not prove, however, that males over 12 living in free-ranging populations cannot show normal spermatogenesis. Our findings indicate that bulls over 12 have spermatogenesis still maintained, although its intensity is markedly attenuated. Since old bulls are not in such a good form as younger ones, they do not dominate in reproduction for behavioural reasons. However, in captivity with the group structure completely different from that observed in free herds, European bison bulls continue matings effectively up to 15 years of age (Krasiński and Raczyński 1967). 


\section{Conclusions}

The results of the histological studies of the testes and epididymes allowed the definition that male European bison living in free-ranging populations and reserves begin to mature sexually at 3 years of age. Bulls aged 4-12 years are characterized by fully developed spermatogenesis, which means that they are able to produce mature spermatozoa. Males over 12 years show the attenuation of the spermatogenic process.

Acknowledgements: We should like to thank Prof Z. Pucek for his valuable remarks concerning the earlier version of the manuscript. We are grateful to Dr Z. A. Krasiński for his assistance in collecting the material and for the documentation on culled animals, as well as to technical staff of the Mammal Research Institute, PAS, in Białowieża for their help with the preparation of the material for further investigations.

\section{References}

Basrur P. K. 1969. Hybrid sterility. [In: Comparative mammalian cytogenetics. K. Benirschke, ed]. Springer Verlag, New York: 107-131.

Bomba G. 1995. [Pathomorphologic investigations of the testis of the European bison and domestic cattle hybrids]. Ph D thesis, University of Agriculture and Technology, Olsztyn: 1-90. [In Polish]

Caboń-Raczyńska K., Krasińska M. and Krasiński Z. 1983. Behaviour and daily activity rhythm of European bison in winter. Acta Theriologica 28: 273-299.

Caboń-Raczyńska K., Krasińska M., Krasiński Z. A. and Wójcik J. M. 1987. Rhythm of daily activity and behavior of European bison in the Białowieża Forest in the period without snow cover. Acta Theriologica 31: 335-372.

Chaplin R. E. and White R. W. G. 1972. The influence of age and season on the activity of the testes and epididymes of the fallow deer (Dama dama). Journal of Reproduction and Fertility 30: 361-369.

Chapman D. I. and Chapman N. G. 1970. Preliminary observations on the reproductive cycle of male fallow deer (Dama dama L.). Journal of Reproduction and Fertility 21: 1-8.

Fedyk S. and Krasińska M. 1971. Studies on the spermatogenesis in European bison and domestic cattle hybrids. Acta Theriologica 16: 449-464.

Fecyk S. and Krasińska M. 1980. Spermatogenesis in backcross generations of European bison and domestic cattle hybrids. Acta Theriologica 25: 201-212.

Gosch B. and Fischer K. 1989: Seasonal changes of testes volume and sperm quality in adult fallow deer (Dama dama) and their relationship to the antler cycle. Journal of Reproduction and Fertility 85: 7-17.

Haugen A. 1974. Reproduction in the plain bison. Iowa State Journal of Research 49: 1-8.

Hochereau-de Reviers M. T. and Lincoln G. A. 1978. Seasonal variation in the histology of the testes of the red deer, Cervus elaphus. Journal of Reproduction and Fertility 54: 209-213.

Jaczewski Z. 1958. Reproduction of the European bison, Bison bonasus (L.) in reserves. Acta Theriologica 1: 333-376.

Korobko Yu. A. and Kurnosov K. M. 1979. [Morphology and histology of genital system]. [In: European bison. Morphology, Systematics, Evolution, Ecology. V. E. Sokolov, ed]. Izdatelstvo Nauka, Moscow: 413-434. [In Russian]

Korwin-Kossakowski J. and Sumiński E. 1984. Development of gonads and spermatogenesis in hybrids of European bison and domestic cattle. Acta Theriologica 29: 413-424.

Krasińska M. and Krasiński Z. A. 1995. Composition, group size, and spatial distribution of European bison bulls in Białowieża Forest. Acta Theriologica 40: 1-21. 
Krasiński Z. 1967. Free living European bison. Acta Theriologica 12: 391-405.

Krasiński Z. A. 1978. Dynamics and structure of the European bison population in the Białowieża Primeval Forest. Acta Theriologica 23: 3-48.

Krasiński Z. A. 1994. Zagrożenia populacji żubrów w Puszczy Białowieskiej. Łowiec Polski 8: 6-7.

Krasiński Z. A. and Krasińska M. 1992. Free ranging European bison in Borecka Forest. Acta Theriologica 37: 301-317.

Krasiński Z. and Raczyński J. 1967. The reproduction biology of European bison living in reserves and in freedom. Acta Theriologica 12: 407-444.

Krasiński Z. A., Bunevich A. N. and Krasińska M. 1994. Characteristic of the European bison populations in the Polish and Belarussian parts of the Białowieża Forest. Parki Narodowe i Rezerwaty Przyrody 13: 25-67. [In Polish with English summary]

Kulagin N. M. 1919. Zubry Belovezhskoj Pushchi. Izdatelstvo Moskovskogo Nauchnogo Instituta, Moskva: 1-166.

Kulagin N. M. 1932. Gistologicheskoje strojene semenikov zubra. Izdatelstvo Akademi Nauk SSSR Otdelenie matematicheskikh i estestvennykh nauk. Ser. VII. 1, Leningrad: 99-100.

Lincoln G. A. 1971. The seasonal reproductive changes in the red deer stag (Cervus elaphus). Journal of Zoology 163: 199-204.

Lincoln G. A. 1981. Seasonal aspects of testicular function. [In: The testis. H. Burger and D. de Kretser, eds]. Raven Press, New York: 252-302.

Loudon A. S. I. and Curlewis J. D. 1988. Cycles of antler and testicular growth in an aseasonal tropical deer (Axix axix). Journal of Reproduction and Fertility 83: 729-738.

Piusiński W., Bielecki W., Malicka E., Kita J., Dziąba K., Osińska B., Anusz K., Kowalski B. and Lenartowicz-Kubrat Z. 1997. Pathomorphology and pathogenesis of diseased genital organs (prepuce and penis) of bison in the Białowieża Forest. Medycyna Weterynaryjna 53: 596-600. [In Polish with English summary]

Raitsina S. S. 1985. Spermatogenez i strukturnye osnovy ego regulyatsii. Izdatelstvo Nauka, Moskva: 1-201.

Shult M. J. 1972. American bison behavior patterns at Wind Cave National Park. Ph D theses. Library. Iowa State University, Ames: 1-135.

Świeżyński K. 1968. The male reproductive organs of the European bison. Acta Theriologica 13: $511-551$.

Webster J. R., Suttie J. M., Veenvliet B. A., Corson I. D. and Labes R. E. 1992. Changes in live weight and the reproductive tract of farmed red deer stags from 6 to 27 months of age [In: The biology of deer. R. D. Brown, ed]. Springer-Verlag, New York: 339-342.

Węgrzyn M. and Serwatka S. 1984. Teeth eruption in the European bison. Acta Theriologica 29: 111-121.

Wróblewski K. 1927. Żubr Puszczy Białowieskiej. Wydawnictwo Polskie, Poznań: 1-234+XVI.

Zablocki M. A. 1949. Neobkhodimost izuchenya osobennosti zubra i ego vosstanovlene v SSSR. Nauchno-Metodicheskie Zapiski 13: 128-146.

Received 27 April 1998, accepted 11 December 1998. 